\title{
The military, law and sovereignty: Several remarks about the military and its function in preserving the law and state
}

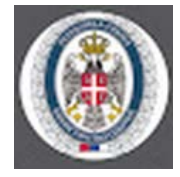

Published: 06/12/2021

Corresponding author: Jovan Babić

Correspondence email: jovanpbabic@gmail.com

DOI:

10.5937/vojdelo2103002B

\author{
Jovan Babić(ic \\ Univerzitet u Beogradu, Filozofski fakultet
}

\section{Abstract:}

This article does not contain an abstract.

Keywords: This article does not contain key words.

\begin{tabular}{|l|l|l|l|}
\hline c & e & o & n \\
\hline c & e & e & s \\
\hline
\end{tabular}

The role of the Serbian Armed Forces was clearly seen last year, when, faced with the Covid pandemic, they raised the hospital capacities of Serbia to a much higher and more demanding level in a few days. This could not have been done by any other institution at that moment and in such short time. It could be noticed that everything was done without much pomp, simply according to the task assigned to the military - and that is to effectively defend the institutions of collective life from a great and threatening attack. What was attacked? The answer to this question also contains the answer to the question of what the role of the military is in the overall life, both collective and individual one which fits into collective life and there finds the possibility to achieve what life makes life: the ability to set some goals and then, to properly and neatly find the means to successfully achieve these goals.

It is a basic scheme of how values in the world are fulfilled-as a manifestation of freedom - and how then the values get their deeper and lasting meaning in the accumulation of achievements that make up the overall well-being of a society and give final justification to everything we do. We do not have that, for example, in the values that give us current pleasures, for which it is not important that they are based on something more lasting and stable and be something we will be proud of at the end of life. What is the role of the military in all of this and why does it exist?

At first glance, it may seem that the values that give meaning to life are implied and in a way inviolable. But are they? In fact, this question is directly related to the question that is essentially metaphysical, and which is easy to answer, but difficult to explain: is freedom possible without uncertainty? No, it is not. Freedom, as the power to set some, any, goals and then try to achieve them - and we have defined life as the activity of setting goals and their achievement - is the power to make it different than it would be without it, as the decision - making power comprising it. However, that power does not produce its effect automatically, but enters the dialectic of working on the achievement of those set goals, and it is quite possible that the effect will not be achieved, that it will not succeed. Freedom functions in the medium of uncertainty. 
Life in freedom is not mechanical (unlike biological life, which is mechanical, and where everything goes according to causal necessity). However, and that is also the essence, as the power freedom is not the lottery of wishes and imagination, left at the mercy of mere coincidence. The essence is that coincidence, which looms there as danger, is overcome in freedom by the control of the future that freedom as the power represents. This power of the control of the future is the basis for predictability, and then for planning and decision-making, and finally for the fulfillment of all goals that are set and whose achievement represents success and value. In order for that to be possible, it is necessary to arrange life so that it is correct and predictable, and the law serves this purpose, what the state is in charge of, which has to be able to provide that.

It is not the function of the military to regulate the ongoing processes of goal setting-this will be done by people and their collectives to the best of their ability and ambition, nor to control their orderliness - it will be done by various administrative services and, ultimately, if necessary, the police, but to be a guarantor of the state's ability to enforce the law, and if necessary, to defend such a guarantee from the uncertainty which may endanger it. This is what we saw when the Serbian military built hospitals in a few days last year. This is what we did not see when the other army, the Yugoslav People's Army, allowed the subject of its defence, the state that we all remember, although we cannot say exactly what it was, to simply collapseand its enormous "firepower" remains only an idea, even though it really existed. This is what makes the role of the military specific in the dialectic of goals and means: it should stand and wait, like a bill of exchange and title deed to property, and also to "wake up" when needed. As it was in the spring last year. However, when we look more closely, we can see that this is how the law works: as a warning not to do what should not be done. The law stands passively and waits to be implemented, with the hope that it will not be necessary, but with willingness to become precisely active if needed. And there lies the metaphysical essence of the military: it is the location where collective freedom is concentrated, the freedom that the state emerges from as a permanent and orderly expression of collective life.

Predictability is a condition of permanence and stability, it implies objectivity and principle - where the military draws its political neutrality from. In that sense, it can be said that it has a pre-political and supra-political status. Its function is not to ensure law enforcement, but to defend the assumptions necessary for law enforcement. Its position is directly defined by the function of defending these assumptionsthe defence of the state as the system that regulates the life of people together, in case of an attack or a threat of an attack.

This difference between an immediate attack and a potential attack seems simple, but actually it is not: where does a threat of an attack belong to, an actual or just a potential attack? This is precisely the dialectic of the defence: the defence becomes effective when it turns into a counter-attack, and each action that can be plausibly defined as a counter-attack is a legitimate function of the military. A latent attack is responded to by the latent defence: by discouraging the attack. The defence will be effective, both at war and in peacetime, to the extent to which predictability is possible. This means that the military is most effective if an attack does not occur, if it is prevented by its presence. Here we can see a connection between the notions of predictability and stability: stability is a condition of solidity, both the solidity of the political system and the solidity of life itself, collective and individual one. Peace can be defined as the state of stability. What kind? The one that enables the control of the future time, i.e. the actual functioning of the law in force. All this requires solidity, as a condition of trust in the validity of the law, which is the essence of peace. Nowadays it is popular to talk about just peace.

However, we should not forget that peace is the cause of war. How? By waging war over what the definition of peace will be, some new one or a new definition of that old peace. An ultra-minimal definition of peace is that it is the articulation of valid, i.e. normatively and factually accepted distribution of power in a society. In peacetime, it is clearly and precisely defined what are legitimate and illegitimate actions, and then, presumably, what legitimate and illegitimate wishes are (illegitimate wishes, if fulfilled, are those causing the existing peace to be endangered or destroyed). In order to preserve 
the stability of this predictability (predictability of what the law will be tomorrow, and not only what the law is today, or what it was this morning), a convincing force that can effectively defend the current system of established expectations is needed, and also to show in advance the readiness to do what is necessary to make it happen. That is why a definition is important for the military-it is actually the key factor of its potential success.

The military should be strong, of course. But, although the quality of weapons (which is also the symptom of the seriousness of the state and its self-esteem) and competence (which is the symptom of the seriousness and self-esteem of the military) are very important parameters of its quality and condition for its success, still the main factor is actually the determination to defend the state. The example of Finland, which managed in 1940 to defend its freedom from the army of the Soviet Union, that only three years later, defending its country, defeated the German Wehrmacht, until then the greatest military force in human history, can convincingly serve as an illustration. This example clearly shows how coincidence and necessity, two forces that play a huge role in everything that happens, can be overcome if there are those resources that can make the defence really the most successful, primarily those resources that are noticed in the precision of concepts, determination of intention and perseverance in acting. This example shows how freedom, when it really exists, i.e. when those who fight for it really care about it, can overcome both coincidence and necessity. Without these resources, weapons and competence are just mere inertia without freedom and, as we saw in 1991 and 1992, lead to confusion, indecision, incompetence and, ultimately failure. Definitions are the most important, they precede everything else. However, they are valuable only if they provide knowledge of the essences, and that will be the case if those who use them care about knowing their content: to know who and what they are and what they defend.

Of course, we can ask ourselves why the military is needed at all, and could it be, like many other "services", replaced by some service that would do it professionally and expertly, on request? We live in an age of comprehensive expertise, don't we? The answer to this question is actually much more complex than it seems at first glance. It depends on the nature of human life together, and that again depends on whether we care more about pleasure and happiness in the present, or the continuity of life, like ours, in the future. Whether, for example, we think that it does not matter what will happen "after us". This problem has occurred before, each time the processes of globalization have managed to suppress autonomy and heterogeneity, contained in both individual and collective freedom and brought the world to the brink of simplification, where it is really possible to abolish the distinction between the military and the police - because there is no state anymore, no people, no future that is different and depends on what we want, and in which the difference between the future and the present will be "overcome" because all differences will be "abolished". In such a world, there are only individuals, who formally freely enter into mutual arrangements that can be defined in the form of a contract, and in which the essential life forms will be drowned in the ecstasy of narcotic happiness at the present moment.

This image corresponds to one of the two ways in which states can be articulated - empires. They differ from nation states precisely in the fact that they have transferred all sovereignty (the power to make their legitimate decisions independently, without the obligation to legitimize them with someone else's consent) exclusively to individuals, and their relation to a guiding idea, or God. In such a situation, the function of the military can really, like everything else, become an expert matter, a matter of evaluation and free contracting - because freedom itself is a matter of "free" contracting, and then in the definition of what is defended there is no collective identity, but it becomes all the same whether we rule over ourselves or someone who knows better what is in our interest rules over us. It is possible that the economic productivity of such a system of life, due to the intensity of competition that exists in it, is higher and that it, like empires throughout history, will be richer and give more chances for various forms of satisfaction and enjoyment. It should not be said that in such a system there is no freedom-it is more correct to say that there is no need for freedom, then not for dignity, self-esteem and respect of others, for distinguishing one's own and other's, for one's homeland, etc. because it all sinks into the intensity of happiness in a permanent sense of continuous satisfaction in 
the present. In such a world, the difference between the military and the police is really lost, in such a way that the military becomes the police, so the military in our abovementioned definition of defence does not exist anymore: there is no need to defend anything, what is needed is to make everyone happy, and what a war once was becomes "a struggle for (their) hearts and (their) souls" (while those who selfishly defend their freedom depend only on the sincerity of their will to resist this seductive process).

Today, the popular thesis about the "obsolescence" of the term "sovereignty" (because all sovereignty is monopolized in the description of a valid ideal that does not depend on what someone, or some, specifically and freely wants, because it is only important that the world "becomes better"), there is no need anymore for such expensive, cumbersome and complicated schemes like, for example, compulsory military service. Military service is a characteristic of nation states, and not empires, those states in which one can speak of a people's army, and in which the notion of sovereignty is not considered to have lost its meaning. In empires, the very notion of people has a completely different meaning, the meaning according to which nationality and citizenship are completely equalized and reduced to some impersonal amalgam, as in corporations - empires are corporations, they do not have homeland, true national identity (when they fail they are not renewed), extend in the space as far as they can control it, etc. Therefore, in empires the armed forces can only be professional because people are not necessary for its essentially semi-police purpose: the result is the belief in the possibility of the police control of the world (that is why we had the US military patrolling in Iraqi cities, and such equalization of the military and the police, as we have seen, has collided with the elementary logic of life and produced only violence, unnecessarily and unsuccessfully - but this police use of the armed forces, even foreign ones, has destroyed the state that has barely and, as it seems, only partially recovered).

However, when there is an external or catastrophic attack, then empires have also to resort to mobilization. That is why the military is so important, especially in nation states, those ones that respect themselves and do not have imperial and globalist pretensions of controlling foreign territories, but are ready to defend themselves.

If, like in nation states, the role of the military is to ensure that the legislative will can be constituted and function (to ensure the ongoing stability of peace and security of decision-making), then it is a matter for everyone. The law is everyone's business, but its defence (not its implementation) is precisely the task of the military. Therefore the military is general, and not expert, it belongs to everyone who is interested in continuing life defined by the valid law. Although this cardinally limits the scope of the military tasks, especially in peacetime, it is still not possible to predict in advance what exactly will be the source of a cardinal threat to the society and its state. Therefore, the military has to be constantly vigilant, and consider accurately what is happening (and not like the Yugoslav People's Army, which defined itself the task of "the defence against an external enemy", and then calmly watch how the reason for its existence disappears in the destruction that, accidentally, did not fit into such a truncated definition that prevented it from even trying to defend what it was supposed to defend). For example, the Article of the 1974 SFRY Constitution that, under the threat of death penalty, forbade the "capitulation of Yugoslavia" destroyed the command capability of the Yugoslav People's Army (a commander is not the one who has to enter a total war and sacrifice his entire army even when the goal of the fight is precisely defined - and this is how we assumed that the absence of one signature would make something to exist that does not exist otherwise). Thus, the military is actually the location where collective freedom is concentrated, the one that the state emerges from as a permanent and orderly expression of collective life.

This means that the state cannot be defended only by professionals, just as it cannot be defended (only) by volunteers. In the event of an attack, mobilization will involve literally everyone (everyone is the subject of defence, one way or the other), and therefore it is better for at least some of them to be really ready. It is a moral duty of the state to reintroduce compulsory military service, and the only thing to consider in this context is whether in the new division of labour in which those differences 
that were characteristic of the traditional division of labour into "male" and "female" jobs are lost, this obligation should literally include everyone, i.e. women, as well, not just men. For men, there is still (?) the other, independent and strong reason for compulsory military service, but that reason has no direct connection with the military part of this phenomenon as such. It has a deep connection with the need for men to be more or less saved from the disability that their current predominant upbringing, under the strong influence of something we can call "maternal (or parental) possessiveness" imposes (girls are in a much better position because they are not to that extent exposed to the pampering that our civilization persistently cultivates, and which makes it difficult for people to grow up).

It can be said that compulsory military service is justified in nation states, while the concept of professional armed forces and their quality in empires depends on a factor that is partially independent from the fact of the establishment of sovereignty as an expression of collective life: from wealth. Namely, the quality of professional armed forces directly depends on material investment: if you are rich enough, you will be able to buy better professionals, which means that the defence power will directly (and not only indirectly) depend on wealth and that only the rich can ("have the right") defend themselves.

So, unlike nation states, professional armed forces are quite appropriate for empires. There are three reasons for this. Firstly, they are presumably rich, secondly, they do not have a nation, but an unarticulated set of individuals (so that the term "self-defence" gets a slightly different meaning) and thirdly, in connection with the second reason, self-defence and the defence of the value system (i.e. valid ideology) overlap in such a way that the difference between the military and the police is significantly lost (the difference between the defence of the state and order, on the one hand, and the enforcement of order and political correctness on the other, inside and outside the state), so the military can be sent to punitive action, and the police to arm with heavy weapons. The military becomes the police force, and the police an internal army (producing its "enemy" in society itself). The conceptual difference is obvious (and the result may be unexpected: the reduction of the concept of the military to the concept of the police, and validation for the ideological and political use of the military). For a nation state, the military is an instrument of the state self-defence, independent of the political articulation of the state itself, while for empires, political articulation is modus vivendi. These are, of course, ideal type concepts that in reality often overlap significantly.

The military is the pillar and support of the state, the guarantor of its stability and the expression of its readiness to defend, first of all, its constitutional order (sovereignty), and then territorial integrity. It has a constitutive role in the society as an expression of readiness to have its own law that will be an expression of collective freedom behind which there is a serious intention to implement it. The basis of this intention is the condition of authorization for the effective implementation of the law. A state that is not ready to defend itself and its laws does not actually have the right to implement and enforce those laws; it then exists only as a mere illusion, fiction. The seriousness of the intention to defend oneself from the outside and inside attacks is an indicator of the true existence of the state. Such seriousness is manifested in the existence and quality of the military. Normatively, the military is a prepolitical (or supra-political) institution and is exempt, both as an actor and a subject, from everyday political life. In that sense, there is an important difference between the military and the police. The military must not be used as the police force. Its opponents ("enemies") are not criminals and it does not participate in the current regulation of life. The reason for its engagement has to be some cardinal danger that threatens the very foundations of the established order of life - an outside attack, the inside rebellion or something that is not just a crisis, but has the characteristics of a potential catastrophe (natural disasters, epidemics, earthquakes, etc.). Its main engagement is preventive: discouraging and preventing attacks (and catastrophes, if it is predictable and possible), and only when it is necessary, direct engagement. The military has a general social character and cannot be the subject of partial ("party") political structuring. This character is articulated directly and precisely if the main corps of the military is the entire nation, which is ready to defend itself from danger, and that the paid professional part of the military (officers and professional soldiers) is essentially an organizational superstructure that should ensure expert efficiency of the engagement of the military in the defence from 
the danger of the state destruction, anomy and a potential or actual catastrophe. This means, among other things, that the military should not be based on voluntariness (just as law enforcement is not based on voluntariness), but on the universal obligation to serve its purpose, to ensure a normal and lawful life.

\section{Vojska, zakon i suverenitet - nekoliko opaski o vojsci i njenoj funkciji u očuvanju zakona i države}

\section{Sažetak:}

Ovaj članak ne sadrži sažetak.

Ključne reči: Ovaj rad ne sadrži ključne reči. 